\title{
A Blood Indian's Conception of Tribal Life in Dog Days
}

By John C. Ewers, U.S. National Museum, Washington, D.C.

Ed. Note: Mr. Ewers is Assistant Director of the Museum of History and Technology, United Sitates $\mathbf{N}$ a $t$ i o $n$ a 1 Museum, Smithsonian Institute, Washington, D.C. He was the first curator of the Museur, of the Plains Indian at Browning, Montana, located on the Blackfeet Indian Reservation and while there did extensive ethnographic research on the Blackfeet. He has become known as an authority on them and has recently written a book The Blackfeet Raiders of the Northwest Plains. - T. F. Kehoe, S.M.N.H.

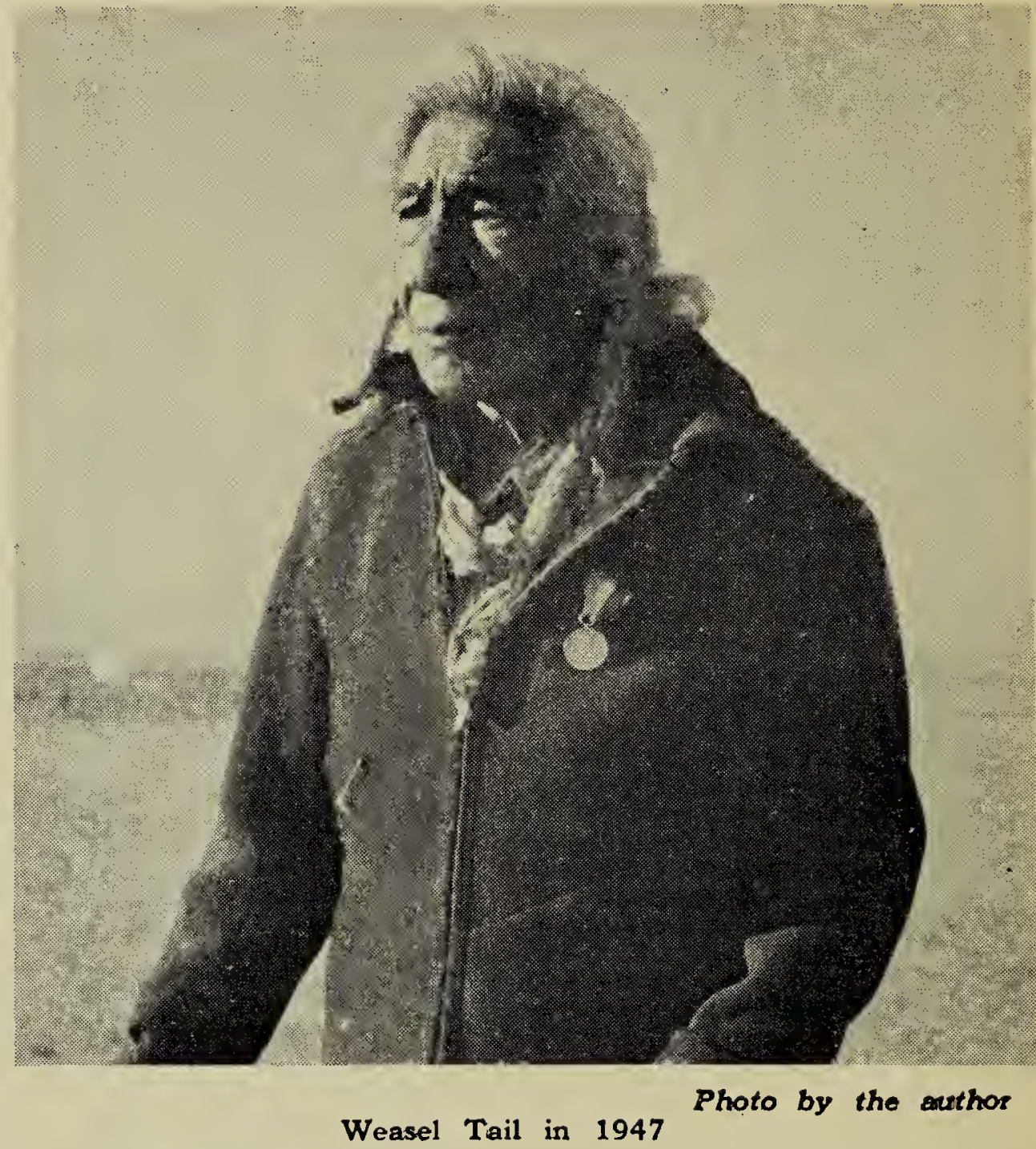

On January 14,1950 , one of the strongest living links between the modern Blackfoot Indians and their traditional past was severed by the death of a little old man bearing the name of Weasel Tail on the Blackfeet Reservation in Montana. Weasel Tail's exact age, like that of other illiterate, fullblood Indians of his generation, was uncertain. The official census for the Blackfeet Reservation for the year 1901 listed Weasel Tail, then the father of a 20-year-old daughter, as 42 years of age. On the basis of this record he must have been some 91 years old at the time of his death, and in his middle eighties during the period 1941-1947 when he served as one of my principal informants.

When I last saw Weasel Tail in the summer of 1947 he was still physically active. His eyes were bright. His mind was clear and sharp. And he still possessed a delightful sense of humor which had made association with him a particular pleasure. Weasel Tail was born and raised among the Blood Indians in Canada, but he had spent most of his adult life among the Piegans south of the border. In his youth and young manhood he had hunted buffalo and had been on a goodly number of horsestealing raids against neighbouring tribes. His memory of the details of Blackfoot life in those days was remarkable. He was also well versed in the rich mythology of his tribe. But unlike most other aged fullbloods Weasel Tail tried to distinguish between mythological explanations of Blackfoat life in the dim and dateless past and the testimony of older Indians whose descriptions were of a more personal nature.

As a young man Weasel Tail had repeatedly questioned some of the oldest men and women of his tribe about the life of the Blackfeet in 
earlier times. Among his informants was a very elderly woman (whom Weasel Tail firmly believed was over 100 years old), Two Strikes Woman, whom he had befriended and who had itold him stories of her great-grandfather's time handed down to her by her father. Another elderly Blood Indian, Victory All Over Woman, recounted to him stories which she had heard during her girlhood from the lips of her aged grandparents who had claimed to remember tribal life in the days before the Bloods obtained horses. From his memories of such conversations as these Weasel Tail described to me some aspects of Blood Indian life in dog days, probably 225 or more years ago.

Certainly I do not contend that these third or fourth-hand reminiscences of an elderly Indian born in 1859 present an unadulterated word picture of Blackfoot life in dog days. But in the total absence of any contemporary observations of Blackfoot customs by literate people in those early times, I believe Weasel Tail's testimony is worth preserving and worth recording for the consideration of students of history and archaeology who are seeking to trace the course of human occupation: of "the Northwestern Great Plains. Weasel Tail's account, which follows, may be of particular interest to students of Saskatchewan history and pre-history because it is most probable that the Blackfoot tribes dwelt within the present boundaries of this province before they acquired firearms and horses and moved westward toward the Rocky Mountains and southward into present Montana.

For the convenience of the reader I have organized Weasel Tail's testimony as follows:

\section{Camp Movements in Dog Days}

When the Indians moved camp all the able-bodied men, women and children old enough to keep up with the others, walked. Sometimes old people, too feeble to walk, were transported on a litter consisting of two cross poles tied between the frames of two travois each of which was pulled by a strong dog.

Lodges were small. Their covers were made of but five or six buffalo skins. These covers were made in two parts, one for the right and one for the left side of the tipi. In setting up the lodge the two sections were laced together along the vertical line of the center of the back of the tipi, then pinned together above the doorway in front. When a lodge was taken down one half of the cover was folded and placed upon the back of a dog. The other half was packed on the back of a second dog. Thus two dogs were needed to transport the skin covering of a tipi. The relatively short poles needed to support a lodge of this size were grouped in small bundles and tied to the cross frames of dog travois so that the ends of the poles dragged on the ground behind.

Cooking pots and soft skin bags containing other household furnishings and utensils were placed upon the oval cross-frames of dog travois for transportation.

\section{Surrounding the Buffalo}

After swift-running men located a herd of buffalo, the chief told all the women to get their dog travois. Men and women went out together, approaching the herd from down wind so that the animals would not get their scent and run off. The women were told to place their travois upright in the earth, small (front) ends up. The travois were spaced so that they could be tied together, forming a semi-circular fence. Women and dogs hid behind them while two fast-running men circled the herd, approached them from up wind and drove them toward the travois fence. Other men took up their positions along the sides of the route and closed in as the buffalo neared the travois enclosure. Barking dogs and shouting women kepit the buffalo back. The men rushed in and killed the buffalo with arrows and lances.

After the buffalo were killed the chief went into the center of the enclosure, counted the dead animals, and divided the meart equally among the participating families. He also distributed the hides to the families for making lodge covers. The women hauled the meat to camp on their dog travois. This was called "surround of the buffalo."

Women fleshed the hides with a buffalo shank bone one end of which 


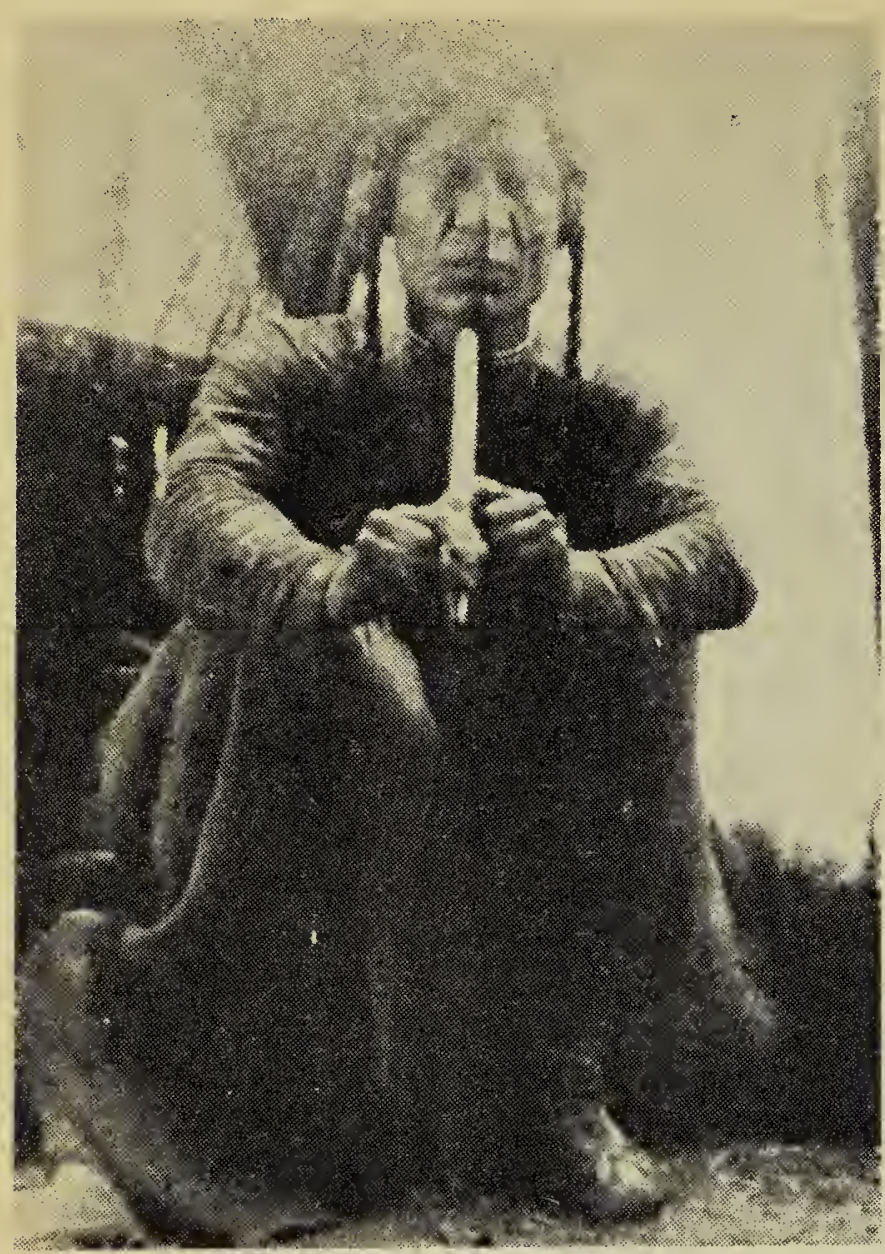

Courtesy Univ. of Pennsylvania Museum Weasel Tail in 1891

was hewn to a sharp edge. They scraped them with a sharp flint bound to an antler handle. They softened the hides by pounding them with rocks.

\section{A Trap for Deer}

Men dug a deep hole in the ground about 15 to 20 feet in diameter. They pilaced supporting posts in the hole and covered it with slim willows, over which they placed grass so that the hole was completely hidden. The men then drove the deer toward the pit. When the deer stepped on the willow covering it gave way and the animals fell into the pit. Then the men killed them with clubs. This was called a "deer fall."

(Weasel Tail said that old Two Strikes Woman showed him a pit of this type, located about 5 miles south of Macleod, Alberta. At the time it was overgrown with vegetation.)

\section{A Trap for Wolves and Coyotes}

Men dug a smaller hole to trap wolves and foxes. They covered it with sticks and grass, and placed manure, entrails and bones of buffalo on top of this covering. At inter- vals around the exterior of the pit they placed bent willows in the ground to which were attached hares. Then they built a fire nearby in which they melted some fat. Animals could smell the burning fat a long way off, and were attracted to the location. When they went for the bait atop the pit they either were caught in the snares or fell into the lightlycovered hole.

\section{Pottery Making}

Women made pottery from crushed rock mixed with sand and water. They dug a little pit in the ground and made a fire in it to harden the earth walls. Then they lined the bottom and sides of the pit with the pottery mixture. While this was still fresh and soft they pushed small stones into the clay at two points opposite each other and near the top of the pit sides. Then they built a fire inside to harden the pot. When it was sufficiently hardened the fire was extinguished and the pot lifted out of the hole by the two stone handles.

(Note: On September 2, 1947, Double Victory Calf Robe, an aged woman on the Blood Reserve in Alberta, told me a variant tradition of Blackfoot pottery making. She said that quantities of sandstone and selenite were ground to powder and mixed with water into a dough. A hole was dug in the ground and the dough was spread over the inner surface of the hole. Boiling water was poured into the hole and allowed to stand for a period. Then the pot was removed, smoothed on the outside, and later used for boiling meat.)

\section{Marriage}

If a young man fell in love with a girl and wanted to make her his wife he hitched a good travois dog to a travois and took it to the girl's father, saying to him, "I will give you these for your daughter." A father of a girl might offer the same' kind of gift to a young man whom he wanted for a son-in-law.

\section{Warfare with the Snakes}

Long ago the Snakes (Shoshonis) and Blackfeet were friendly. But one time a group of Snake and Blackfoot boys were playing a kind of 
football game. One of the Snake boys was hurt. His father became angry and clubbed to death the Blackfoot boy whom he accused of injuring his son. This started the fighting between these tribes.

Scabby Robe was the first Blackfoot Indian to take a Snake scalp. The opposing forces of Snakes and Blackfeet confronted each other on opposite sides of the Bow River near present Gleichen, Alberta. A Snake Indian challenged a member of the Blackfoot parcy to meet $h_{\lrcorner} m$ in single combat. Scabby Robe answered his challenge and the two met in the middle of the river. The Snake threw his "big arrow" (lance) at Scabby Robe. It missed, and Scabby Robe picked it up and killed the Snake with his own weapon. Scabby Robe brough't the body of the Snake ashore and took the scalp as a war trophy. From thast time on there was continuous warfare between the Snakes and Blackfeet.

In those days, however, any man who didn't wish to fight would sit down in the midst of a battle, throw up his hands, and the enemy would not bother him. But one time a Blackfoct Indian did this and the Snakes killed him. Thereafiter the Blackfeet had no mercy for their enemies.

The Blackfoot tribes didn't use shields in their warfare before they obtained guns. Rather they clothed themselves in long shirts of three thicknesses of buckskin. These shirts reached to below the wearer's knees. They were good protection against enemy arrows.

\section{Acquisition of the First Firearms}

The Blackfeet began to acquire guns before they got horses. Before they had any guns the bow and arrow was their principal weapon. They were then friendly with the Crees. One time a party of Blackfeet was in the woods nonth of the Saskatchewan. They heard a frightening noise and began to run away. Some Crees, who had made the noise by shooting a gun, motioned to the Blackfeet and told them to come to them. The Crees then showed the Blackfeet how to load a gun from the muzzle and fire it by pulling the trigger.
Later one cf the Cree young men married a Blackfoct girl and gave one of the new weapons to his fatherin-law. Soon thereafter another Cree married a Blackfeet and gave the girl's father a gun. That is how the Blackfeet obtained their first guns.

Still later the Blackfeet obtained two guns from a trader. When a war pariy set out against the Crows and Shoshonis to the south, they took guns along. And when the enemy heard the noise of these guns they were so frightened that they fled southward from their location near present Calgary, leaving their tipis, their hcrses, and all of their camp equipment behind them. The Blackfeet drove the Crows, Snakes, Flatheads and Nez Percés from the Bow River southward to the Sweetgrass Hills and beyond. The Crees helped the Blackfeet to do this.

\section{Acquisition of the First Horses}

Shaved Head led a war party southward to about the location of the present Blackfeet Reservation in Montana. There they discovered a camp of Indians from west of the Rockies who owned a lot of horses. The Blackfeet stole scme of these animals. When some of the warriors tried to mount the horses the latter began to walk and the frightened would-be riders quickly jumped off. They led the horses homeward. When the people heard that Shaved Head had brought back a pack of "big dogs," they gathered around the strange animals and looked at them in wonder. They put robes on the horses, but when the animals began to jump they ran. After a time a woman said, "Let's put a travois on one of them just like we do on our small dogs." They made a larger travois and attached it to one of the gentler horses. It didn't kick or jump. They led the horse around with the travois attached. Finally a woman mounted the horse and rode it.

The Blackfeet called these first horses "big dogs." Later, because the animals were about the size of an elk, they called them "elk dogs." And that, of course, is still the name for horses in the Blackfoot language. 


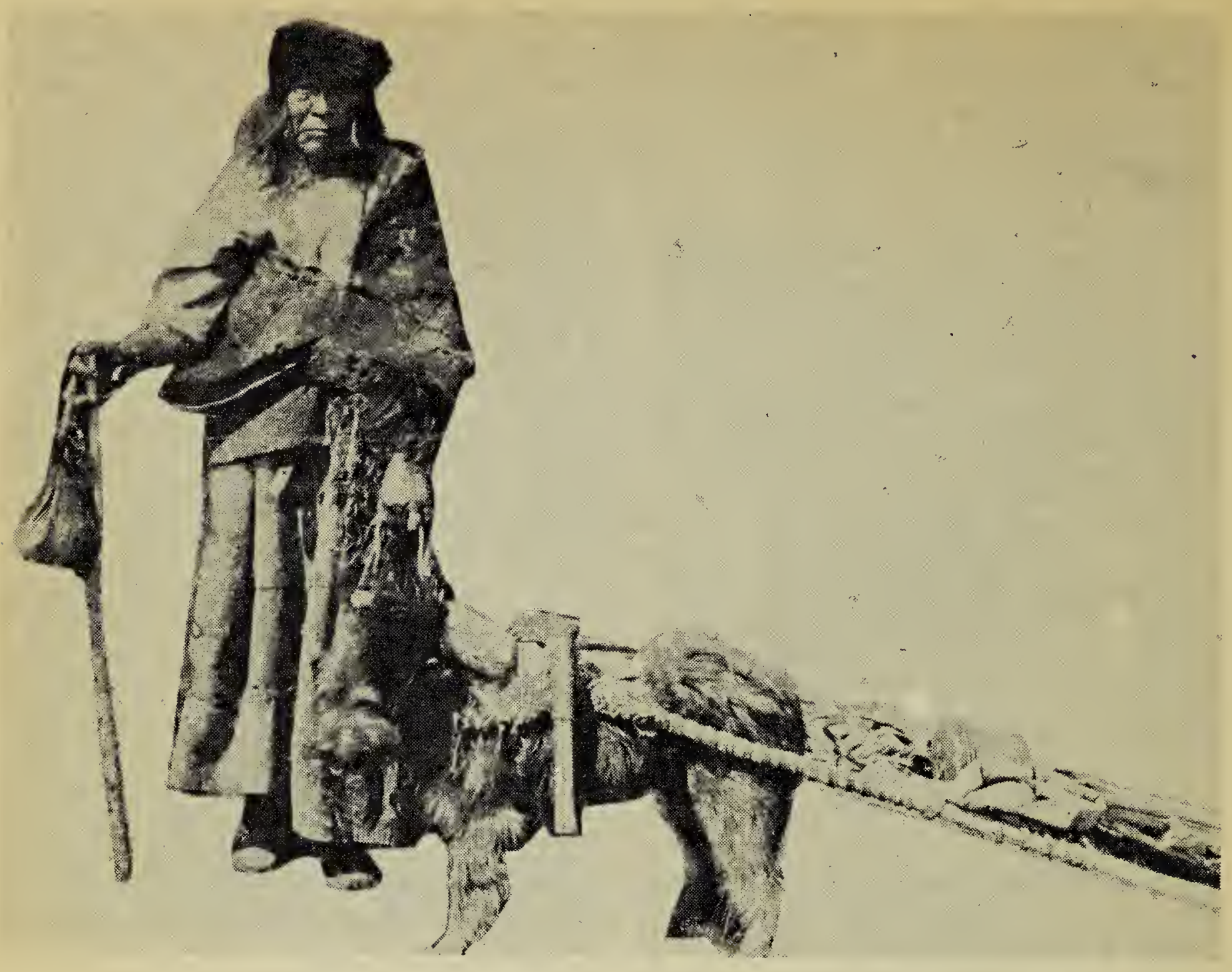

Courtesy Hugh Dempsey

Blood Indian Woman with Dog Travois, 1924

\section{Turtle Stones}

By A. J. Hruska, Gerald

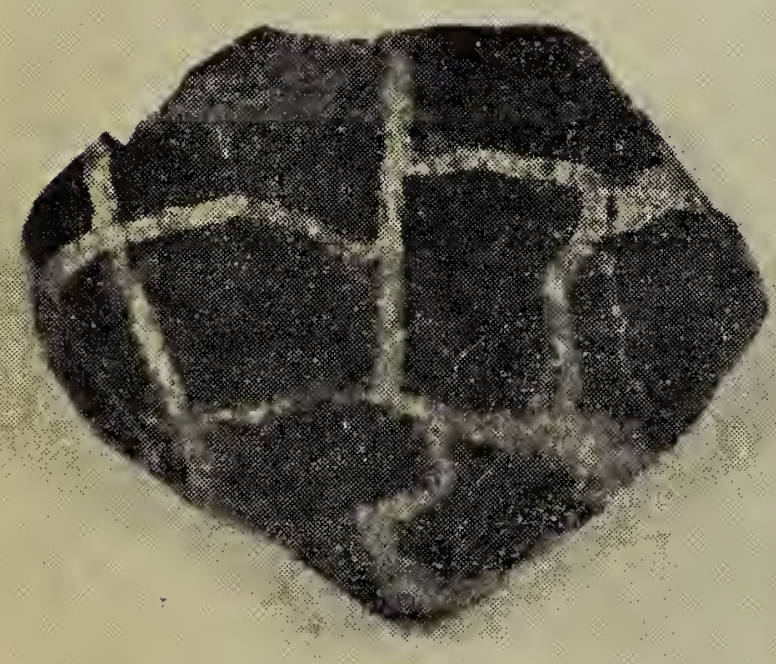

(7) Photo by Cyrìl DeGryse Turtle. Stone
Scattered over our province are interesting rocks which people sometimes call "Tuntle Stones." The marking on these rocks do sometimes, as in the one illustrated, resemble the markings of a turtle carapace, but these rocks are not parts of a fossil tuntle. The Turtle Stone has been formed by the cracking of some early deposit. The polygonal cracks are later filled in by another material, perhaps a calcite. These two rock materials are later exposed and in this case the rock has been waterworn, for its edges are rounded and smoath. 